\title{
Labour Market Challenges in the Pork Value Chain in Poland
}

\author{
IZABELA BUCHOWICZ \\ Institute of Social Economy, Collegium of Socio-Economics, \\ SGH Warsaw School of Economics
}

\author{
HANNA KINOWSKA \\ Institute of Human Capital, Collegium of Business Administration, \\ SGH Warsaw School of Economics \\ ŁUKASZ SIENKIEWICZ \\ Institute of Human Capital, Collegium of Business Administration, \\ SGH Warsaw School of Economics
}




\begin{abstract}
The pork value chain is created by a network of interconnected suppliers and customers, offering meat products to final consumers. Pork production and processing in Poland is highly fragmented, which, together with an increasing global pressure, weakens the engagement of institutional actors in the social dialogue. This makes it difficult to combat negative labour market phenomena such as low wages, long working hours, and a lack of appropriate contracts. In order to diagnose the specificity of labour market challenges in Poland and possible ways of combating them, structured interviews with key stakeholders were conducted. They confirmed the existence of abusive practices in the local pork industry and the need for strengthening the social dialogue. Conclusions from the research include recommendations for further exploration of the issue.
\end{abstract}

Keywords: labour market, industrial relations, pork value chain, Poland

JEL Classification Codes: J53, J54, J41

\title{
Introduction
}

Today the meat industry is changing under the pressure from global competition as well as aggressive retail pressures. It is pushed towards increasing reduction in costs, with obvious harmful effects on employment terms and conditions, as seen through the development of the 'social dumping' phenomenon (Bernaciak, 2015; Eurofound, 2016). However, in the meat industry (production and processing) labour is the second major component of production costs. In spite of the increasing modernisation of the production process, it still employs a high number of unskilled manpower in tough working conditions.

In recent years, the pork value chain in Poland has undergone many changes. They resulted both from the dynamics of legal conditions as a consequence of Poland's accession to the European Union, increased international competition, integration processes within the sector and random events (e.g. infectious diseases such as ASF). The pork production sector is based on human labour. The fragmentation of the sector and the challenges of the labour market in Poland result in the lack of systemic solutions enabling social dialogue.

The authors formulate a thesis that the weakness of social dialogue has a negative impact on the functioning of the labour market in the changing conditions of the pork value chain in Poland. On the basis of the literature, the conditions of the analysed value chain were determined, covering the specificity of the labour market. The challenges were examined basing on qualitative research carried out within the framework of the project Fairness, Freedom and Industrial Relations across Europe: up 
and down the meat value chain (MEAT.UP.FFIRE) VS/2018/0014, European Commission budget heading 04030108 Industrial relations and social dialogue, VP/2017/004, Improving expertise in the field of industrial relations).

\section{Pork value chain in Poland}

The pork value chain constitutes an important part of meat production in Poland. Pigs are the most important species of farm animals in Poland. According to the data collected by Statistics Poland for 2016, its share in the structure of global agricultural production amounted to $10.9 \%$ and in commodity production to $13.19 \%$ (GUS, 2017). The value chain of pork meat is created by a network of interconnected suppliers and customers, offering meat products to final consumers. The structure of pork supply in Poland is characterised by high fragmentation of production, processing and distribution.

The large number of dispersed entities and the lack of strong capital ties of breeders with the meat industry do not foster sustainable integration. That is why diversification of activities plays an important role in maintaining profitability. Entities operating on the market, due to their small size, try to diversify both vertically and horizontally - producing different types of meat. Industry leaders who offer a wide range of products rely on greater integration of the supply chain. Smaller manufacturers focus on developing their own distribution networks.

In order to understand the characteristic structure of the Polish pork market, it is good to use a comparison with Denmark - the most important European pork producer. In Poland, the production of pigs is carried out by about 600,000 farms, as compared to only 7,000 Danish farms. The average herd of the Polish producer is about 70 animals, compared to 2,500 in Denmark. Finally, the slaughtering of pigs is carried out by nearly 600 plants in our country, while in Denmark there are two processors, with several local branches (Szymańska, 2017).

Factors influencing the shape of the pork value chain in Poland are complex. They include fluctuations in prices of pork livestock, both in Poland and in the European Union, as well as formation of prices of means of agricultural production. For a vast majority of economic entities operating on a highly dispersed market, the variability of both elements - with a low scale of production - is of critical importance for their continued existence. This results in a very unstable supply of the internal pork market and forces processors to look for complementarities from imports. Random situations also play an important role. Infectious diseases, such as the African Swine Fever virus (ASF) or other similar epidemiological threats are the main threats to breeders and herds. 
An important feature of the Polish pig market is the excessive fragmentation of farms, which results in a small scale of production, making it impossible to obtain significant economic effects and accumulation of capital. The number of pig farms has been gradually decreasing for years. At the end of the $1990 \mathrm{~s}$ there were still 1.5 million of them. According to the data from 2015, it is estimated that there are currently slightly more than 200,000 of them (Szymańska, 2017).

Along with the decrease in the number of farms and simultaneous increase in the number of herds in entities remaining on the market, the average size of breeding significantly increases. In the years 2007-15, the average herd size increased almost threefold, from 26 to 70 units. The size of the herd is important for the profitability of production. Economic estimates from several years ago indicate that only herds of about 50-60 sows will be able to generate income, allowing them to stabilise and develop moderately (Szymańska, 2017).

At the beginning of the second decade of the $21^{\text {st }}$ century in Poland there was a rapid - of more than 20 percent - decline in the pig population. The reasons for this state of affairs should be seen in the conditions in which pig breeding is carried out in our country, significantly deviating from the standards in European countries. This has a direct impact on the efficiency and competitiveness of the pig production sector. The unfavourable - in terms of economic profitability - structure of herds makes it impossible to make efficient use of resources. High fragmentation and individual character of breeding results in the lack of appropriate specialists in this field and a professional approach to the issue of production organisation. Despite the still current restrictions in the development of pigs, in recent years it has been possible to stop the rapid decline in the number of herds and stabilise the volume of breeding (GUS, 2017).

Both export and import play an important role in the production of pork in Poland. Polish producers export pork products to the European Union countries as well as the United States and Canada. In 2017 Poland exported 765 thousand tonnes of livestock, meat, processed pork products and fats (in carcass equivalent), 9\% more than a year ago. Exports of meat, preserves and livestock increased, while exports of fats decreased. In 2017, import exceeded export and amounted to 893 thousand tonnes and was $3 \%$ higher than in 2016. Poland imported mainly meat and livestock (Bureau of Analysis and Strategy..., 2018).

There were over 2.6 thousand enterprises in the meat processing and production sector in Poland in 2017 (Table 1). Of all the entities, 40\% are small companies with fewer than 9 employees. The consolidation of the industry is taking place very slowly - in the years 2007-15 the number of meat processing plants employing 9 or fewer employees decreased by only 15\% (PKO BP, 2018). 
Table 1. Number of companies in the meat processing and production sector in Poland

\begin{tabular}{|l|l|l|l|l|l|l|l|l|}
\hline 2008 & 2009 & 2010 & 2011 & 2012 & 2013 & 2014 & 2015 & 2016 \\
\hline 3283 & 2921 & 2857 & 2692 & 2787 & 2448 & 2486 & 2730 & 2683 \\
\hline
\end{tabular}

Source: PKO BP Bank's Report (2018).

The integration process of the industry is organic due to the lack of capital links between livestock producers and meat processing plants. High market fragmentation is not conducive to building long-term relations. Cooperation between slaughterhouses and suppliers is very limited. Slaughterhouse managers are often accused of shortsighted import policy. They do not build lasting local ties with suppliers and do not care about creating their own stable raw material base (Szymańska, 2017).

Labour market characteristics in the pork value chain in Poland

It is difficult to discuss the characteristics of the labour market in pig meat farming and production due to the lack of access to full sector statistics. Fragmentation of farms engaged in breeding or family businesses, slaughtering, cutting and meat production, significantly obscures the situation in the industry. Another major limitation on access to data is the fact that companies whose shares are not listed on the stock market have only a limited obligation to submit their financial statements and information on themselves to the register. This register is not available online. A large proportion of entities only provide basic data and do not provide financial information. However, available data (Table 2) indicate that the number of employees in the meat production and processing sector oscillates around 119-118 thousand.

Table 2. Number of employees in the meat production and processing sector

\begin{tabular}{|c|c|c|c|c|c|c|c|c|}
\hline 2008 & 2009 & 2010 & 2011 & 2012 & 2013 & 2014 & 2015 & 2016 \\
\hline 123572 & 121314 & 122948 & 118437 & 119494 & 118089 & 119616 & 118821 & 118226 \\
\hline
\end{tabular}

Source: PKO BP Bank’s Report (2018).

From the available data related to trends in the industry, it can be concluded that the level of employment will decrease in the coming years. The reasons are the decreasing number of entities on the market, mergers of production companies, which always entail the risk of eliminating the duplication of jobs, and finally the construction of modern plants, which focus on greater automation of production.

Although no direct data on salaries in the pork sector are available, anecdotal evidence and interviews with sector representatives indicate that they oscillate between the minimum wage and the median of earnings in Poland. Only specialist 
positions that are important from the point of view of continuity and quality of production can go beyond the scope indicated. The location of workplaces in areas with a smaller population density and the ease of obtaining labour do not augur well for significant changes in the trends in the nearest future.

Automation processes, which aim to replace human work with a wider use of machines, also will not be a significant stimulus for raising salaries in the industry. They will certainly have a negative impact on the number of people employed. Notably, there is no separate research on the working conditions or observance of labour law provisions for the pork production chain. ${ }^{1}$

\section{Labour market challenges in the pork value chain in Poland: the results of the qualitative research}

Analysis with an aim to identify the specific aspects of industrial relations and labour market within the pork value chain in Poland was the result of the research undertaken within the project Fairness, freedom and Industrial Relations across Europe: up and down the meat value chain (MEAT.UP.FFIRE). The overall goal of the project is to understand whether there is room for social dialogue improvement, possibly promoted and supported by ad hoc regulatory actions, common strategies, initiatives with positive effects on workers in terms of income, working conditions, and social inclusion. For the purpose of this article, there were selected aspects concerning labour market challenges and characteristics of the value chain in Poland which may be related to social dialogue.

As part of the field research we conducted eight direct in-depth interviews: two interviews with experts, two interviews with producers of pigs (one of them belongs to a local association), one interview with an independent veterinary inspector, one with an organiser of contracts and two interviews with employees at the processing factory. All interviews were performed personally according to the structured questionnaire prepared by the leader of the project. ${ }^{2}$ All the interviews were recorded, and the detailed transcription was prepared. The interviews were of different length: from forty-four minutes up to one hour and six minutes.

The experts who participated in the project interviews were professors interested in pig farming and specialising in pork value chain from SGGW (Warsaw University

1 The relevant data of the National Labour Inspectorate regarding health and safety at processing of meat will be available in 2019 .

2 All partner countries conducted the field research using the same methodology, which was accepted by the European Commision. 
of Life Sciences). Producers who participated in our research have their own pig production farms in the east of Poland. The independent vet inspector conducts veterinary checks in several pork processing factories (small and big ones) in eastern Poland. The person who is an organiser of contracts cooperates with piglet producers, pig producers and processing enterprises in the eastern part of Poland. The men who work at the processing factory are employed by a big factory owned by foreign capital.

The interviews were conducted in a very difficult time when Polish media focused on problems and unfair practices in processing factories. We had a big problem to find people who were not afraid to talk to us and agreed to be recorded.

The interviews confirmed that the structure of the pork production chain in Poland in not homogeneous. It has a few variants: ${ }^{3}$

1. Production of piglets on a large scale on specialised breeding farms, which ensure genetic material of good, controlled quality for production of porkers. Production of piglets is carried out annually in a few cycles. The number of cycles depends on a scale of piglet production. Genetic material of piglets is the most important indicator of good meat, i.e. right content of 'meat in meat'. Through permanent contracting, piglets are delivered to porker producers. Producers rear pigs until the moment when an animal reaches the right/expected weight. Then, porkers are sold to a middleman who delivers them to an abattoir (slaughterhouse) or to a processing enterprise carrying out multi-stage production which has its own abattoir. From the abattoir the carcass goes to an undressing unit, where meat is classified and distributed into appropriate production units. Prepared meat enters the production, in the effect of which it leaves the processing enterprise and goes to trade middlemen.

2. Production of piglets by small pork producers is insignificant, it is only for their own needs (subsistence). The most often piglets are produced in two annual cycles. Porkers are produced in the same two annual cycles. Porkers of appropriate size most often reach a middleman, who purchases porkers directly from producers on their farms or at procurement point of porkers. The further path of porkers and then carcasses is the same as in the previous case.

3. Production of porkers from small producers, from small farms, also goes to small abattoirs and small processing enterprises, but this type of activity was not analysed in the project.

From the perspective of the interviewers, the situation in the pork value chain changed evidently after 2004, when Poland acceded the European Union. The changes resulted from the Community directives and other lesser documents signed within the scope of international cooperation, guaranteed supplies of piglets and

\footnotetext{
3 Interview with Expert 1 and Expert 2, and also the interview with the Organiser of contracts.
} 
feeds, sales of porkers and meat processing products. ${ }^{4}$ During that time, the foreign capital, most often from EU countries, entered Polish small private enterprises. The current situation in the pork value chain varies, despite uniformed legislation and adopted quality standards.

The situation of persons working in their own production establishments and persons employed in the pork value chain varies strongly. The respondents agreed that before joining the EU, farmers - small pig producers - constituted the largest group of the employed in pork production chain. After 2004, the situation of persons working at different stages of the pork production chain began to change. Currently, the largest group of people are employed in the processing of pork meat.

"The largest number of workers is employed in processing, as processing is simply the most branched, because there is production of meats, preserves, meat products with short and long shelf-life, feed, then there is depository of all and storage which is also included in processing and this involves a lot of people, while purchase in such an enterprise requires a few people - only a few people deal in the entire procurement. In an abattoir, there is also some number of persons employed, but, e.g. 50 people employed in an abattoir will slaughter 2000 pigs on one day, albeit processing these 2000 pigs later requires at least 500 persons, hence in processing". ${ }^{5}$

Family members are employed on small breeding farms. Usually they share their duties. Men perform heavier works such as animal care (feeding and everyday cleaning), cleaning pigpens, taking care of technical condition of machines, loading pigs for transport. The work of women is concentrated on breeding, looking after small piglets and preparation of feed (currently almost entirely mechanised). ${ }^{6}$

Beside the owner, in large pork breeding enterprises there are hired employees. The number of employed persons depends on the scale of production. The larger the number of workers is, the more fragmented work is and the more specialised are their tasks. "I deliver $7000-8000$ porkers a year, while only a few people work for me because my production is mechanised."

Private entrepreneurs, who are subject to labour force shortages, apply barter solutions with their neighbours or relatives. In situations when they are not able themselves or with their permanent workers to complete the necessary scope of work, they use the neighbouring assistance. They 'compensate' for the neighbours' labour input with their own work on the neighbours' farms, be it working with pigs or cattle or, e.g., during harvest.

\footnotetext{
4 From the interview with the Vet and Organiser of contacts.

5 Interview with the independent Veterinary Inspector.

6 Interview with Expert 1.

7 Interview with Producer 1 - member of a local union.

8 Interview with Producer 1.
} 
Worth noticing is the specificity of the workers' structure by the level of education. The internal data of the enterprises which were accessed during the interview indicate that the labour force of pork meat processing is dominated by low educated men with long work seniority. It may be deducted that it is a group characterised with low mobility due most often to their lack of education and elderly age. However, in the same enterprises, a huge differentiation among the labour force (employees) may be observed. A group of employees with tertiary education comprise production technologists, or IT systems operators and financers. Among pork producers, increasingly more often there may be found a farmer with tertiary education who completed the field of study providing knowledge within the scope of pig breeding (and rearing). ${ }^{9}$

"The age of people who maintain pork production has been changing - even 30-40 years ago, they were people more advanced in age, while during the last dozen or so years the largest group among breeders constitute persons aged 30-40 years, hence certainly the youth 'have been attacking' who acquire education at higher schools and often return to their holdings, taking them over from their parents. I do think that the age of breeders will continue to decline all the time, and after some time it will not be most often 30-40 years, but certainly $25-35$ years, or even $20-25$ years at the moment when they maintain the farm together with their parents". ${ }^{10}$

Producers very often participate in courses extending knowledge and improving qualifications. ${ }^{11}$ Abattoir workers adjust their skills mainly to the introduced new technologies. This scope of work does not require any particular education. Both experts interviewed in the project pointed out the fact that work in abattoirs requires particular psychical predisposition and it is most often performed by seasonal workers, and then they change work positions or enterprises together with the scope of work. The employees of processing enterprises most often have a dozen or so or a few decades long of work seniority at the same enterprise. In the case of low qualified workers, changing jobs requires long commuting, hence high costs of commuting to work, which is very difficult to achieve with their low wages. Similar information was provided by the Veterinary Inspector:

"We cannot generalise here. In agriculture we do not know who breeds [rears] these
pigs or cows. At procurement points and in transport men are employed and they are
not youngsters, but rather men of middle age who are experienced in dealing with animals
and transport. Then, in abattoirs there also work mainly men, as it is very hard work, and
while before accession to the Union mainly Poles worked there, it has entirely changed
recently, because the Polish labour force went abroad, and other nationalities work here,

9 Interview with Expert 1.

${ }_{10}$ Expert 2

${ }^{11}$ Interview with Expert 1. 
meaning Ukrainians, Byelorussians, some Taiwanese or Filipinos - different nationalities work [there]. Thus, it may be said that about 30-40\% [of workers] in abattoirs constitute employees of foreign nationalities, whereas, as regards the processing, the sexes are balanced here, as there are both women and men, albeit the most often they are persons of middle age. Younger people, even if they take up work in such enterprises, leave after a few days or weeks, because they cannot stand this intensity of work and complain about wages. Older workers stay as they cannot go anywhere, they do not have a choice and think that if they have worked here for 20 or 30 years, then they could work for another 10 years, as they will not go anywhere".

At each stage of activities in the pork production chain there are introduced technological changes adjusting the activities of producers (breeders), abattoirs and processing to the norms and standards generally obligatory in the world. The innovative changes in the case of producers are implemented as one-off new investments, e.g. building a new pigpen equipped with advanced feed mixing and distributing devices, or (devices) providing new bedding. Only breeding of piglets (materials for rearing of porkers) is still being organised on the basis of human work. ${ }^{12}$ Machines have not replaced vaccination of piglets or measuring their body temperature. Innovations also facilitate this stage of production: electronically operated warming lamps.

Much more dynamic and wider are changes in processing. Increasingly more advanced technologies facilitate the process of meat preserves production. At the stage of processing, innovations do not only include introduction of new technical solutions such as better machines, but also the (production) process, technology of production has been changing following adoption of the Community solutions, such as the necessity to apply chemical substances, e.g. preservatives, which were not used in Poland before the EU accession. The process of processed meat production accelerated (production lines of a particular product increased) after 2004. Then, there were a few substances not used previously added to the production process. ${ }^{13}$ These attempts are targeted at extending the shelf-life period. From the employee's point of view, these are additional tasks to be performed, while only occasionally there are additional jobs.

Producers make use of outsourcing, such as advisory offices or firms specialising in carrying out particular registers. They order tasks connected with bookkeeping, carrying out the registers of pigs, or completing applications for land subsidies. ${ }^{14}$ They take advantage of services which currently are provided by external firms, while before this work was performed at a production holding, such as purchase of feed

\footnotetext{
12 Expert 1.

13 Interview with a person ensuring starting cooperation and signing contacts.

14 Producer 1 and Producer 2.
} 
with its delivery, maintenance works and repairs of pigpens and machines, etc. Buying piglets for production of porkers is also treated as outsourcing by the producers.

All persons participating in the interviews very reluctantly commented on illegal practices in this field. Nevertheless, the completed interviews allow drawing the following conclusions:

- Small private breeding farms do not employ strangers, outsiders. Here, trust in a worker or a supporting person is important.

- Large breeding farms employ seasonal workers, who are most often residents of the neighbouring villages working on very small agricultural holdings, e.g. 3-4ha and who are not able to maintain themselves exclusively from animal and plant production of their own agricultural holding and are forced to take up casual jobs. ${ }^{15}$

- Meat processing enterprises employ seasonal or long-term workers, while the simplest and hardest work, not requiring qualifications is staffed with prisoners. In other such enterprises, particularly in the western part of Poland, jobs not requiring knowledge and qualifications, albeit at the same time very hard physically and mentally are performed by the workers from Ukraine and Byelorussia. However, those who manage working the longest period under difficult conditions are workers coming from Asia, in particular from Vietnam and Taiwan.

- In large enterprises labour shortages are supplemented with workers employed on temporary, short-term contracts, most often receiving pay below the wages of permanent workers.

- In small enterprises, employers carry out posting of workers, e.g. on the day of collection of porkers, a worker collects and 'disjoints' meat, while the next day he works in the section preparing meat for processing.

- In large enterprises manpower shortages are supplemented with overtime work of permanent employees. In the areas where the labour market is shallow and job offers are scarce, managers of such enterprises do not pay for overtime, assuming that their employees will not give up work without a possibility for alternative employment. In the enterprises situated near large cities, employees are paid for working overtime.

- The problem of most processing establishments is the fact that workers without and with low qualifications work 10-14 hours per day.

The way to reduce the costs related to the costs of labour force depends on the scale of an enterprise and the local labour market where an enterprise operates. Employees defend themselves against injustice of the employers by establishing trade unions within enterprises.

\footnotetext{
15 Interview with Producer 3.
} 
Employees in large firms producing porkers and large meat processing firms unify their forces in the nationwide trade unions, whereas small producers and employees of processing firms set up their own trade unions and local associations. The associations operating locally deal, e.g. with fighting for correct labelling of products. They fight for labelling the products from the Netherlands, Germany and Egypt with the information which country they come from. ${ }^{16}$ Without such labelling, the competition with domestic products is unfair.

"I know that, generally speaking, there is no boom and farmers all over Europe are struggling, but through their (the unions') actions some things were done, e.g. regarding the issue of introducing some stricter sanitary norms, as things are different as regards the products from this richer Union entering Poland - this stirs many doubts, as our products have to meet norms of many tests and certificates, while those other products just enter our market and have it much easier". ${ }^{17}$

In each case (nationwide trade unions, local trade unions and local associations) the members of these organisations can see the effects of their actions. They also notice the external elements which facilitate the effectiveness of actions carried out by trade unions unifying pork producers and processors. In one of the processing firms operating in the east of Poland, there were 5 local trade unions in $2018 .{ }^{18}$ Employees of processing enterprises, similarly to pork producers, have more trust in the organisations operating on a regional or local scale than in the national trade unions. The situation is connected with strong regional and local differentiation in the scale of production, as well as local differentiation in the labour market in respect to the 'availability' of workers.

\section{Social dialogue as the solution to labour market challenges}

According to the conducted research, the sector of pork processing suffers from many problems. Therefore, it provides an interesting field for observation and analysis of many issues: social dialogue improvement (ILO, 2019), working conditions, earnings conditions (employees' income) (Juchnowicz, 2011) and social inclusion (Szarfenberg, 2008). Particular attention should be paid to the specificity of the presented sector, where most workers comprise persons with a very low level of education, without particular qualifications. Well educated persons constitute an insignificant part of the employees in this sector, they consist mainly of specialists

\footnotetext{
16 Producer 2.

17 Producer 2.

18 The interview with a person taking care of initiating cooperation and signing contracts.
} 
and management staff in processing enterprises and some producers of porkers. Therefore, mainly for this reason it is a difficult sector and one worth analysing in the context of the above-mentioned problems.

Efficient functioning of public policy is possible with the use of multiple mechanisms that prevent the appearance of social issues, which may emerge in local environments dominated by one kind of activity. Social dialogue carried out at the level of a working establishment or employees of one branch may, to a great degree, facilitate normalisation and improvement of the situation in a particular branch and as regards the workers of this branch.

According to the official definition of the International Labour Organisation, social dialogue includes

\begin{abstract}
"all types of negotiation, consultation or simply exchange of information among representatives of governments, employers and workers, on issues of common interest relating to economic and social policy. It can exist as a tripartite process, with the government as an official party to the dialogue or it may consist of bipartite relations only between labour and management (or trade unions and employers' organisations), with or without indirect government involvement. Social dialogue processes can be informal or institutionalised, and often it is a combination of the two. It can take place at the national, regional or at enterprise level. It can be inter-professional, sectoral or a combination of these.

The main goal of social dialogue itself is to promote consensus building and democratic involvement among the main stakeholders in the world of work. Successful social dialogue structures and processes have the potential to resolve important economic and social issues, encourage good governance, advance social and industrial peace and stability and boost economic progress" (ILO, 2019).
\end{abstract}

In order for social dialogue to take place, the following must exist:

- strong, independent workers' and employers' organisations with the technical capacity and the access to relevant information to participate in social dialogue;

- political will and commitment to engage in social dialogue on the part of all the parties;

- respect for the fundamental rights of freedom of association and collective bargaining;

- and appropriate institutional support (ILO, 2019).

Including the issue of social dialogue into the field of public policy follows the assumption that non-hierarchised management methods based on direct participation of non-state entities in shaping public policy may result in better efficiency of the state through improvement in the quality of this policy and increasing its effectiveness. These kinds of political strategies are defined as new management methods. These methods involve a wide spectre of processes and institutions, such as the open coordination method, voluntary agreements, setting standards, regulative agencies, regulative networks, management through information or comparing with the best 
(Swaniewicz, 2008). A significant role is played by the state's ability to take root in the society, in other words, the state's ability to penetrate social problems and social preferences, normalisation of social relationships and obtaining resources, as well as their distribution or usage in a particular way. According to this concept, state entities embed themselves strongly in the networks of cooperating units, such as social actors, which provide information and support in the implementation of public policy in particular domains (Towalski, 2017).

The principle of partnership is closely linked to the good will principle and willingness to reach consensus. It means that parties, treating each other as partners, carry out talks intended at complying with the worked-out settlements (Borkowska, 1995). Moreover, one should not forget about political nuances. Social dialogue is manageable only when the number of interest groups involved in the process is small. As it is impossible to reduce the number of interests and interest groups, hence, it is necessary to reduce the number of organisations or institutions entitled to negotiations. Therefore, each group of interest without negotiating rights must find a patron if they do not want to stay unnoticeable (Weissel, 1995). It poses a big challenge to the workers in the pork value chain who tend strongly to organise themselves into small, local associations instead of participating in trade union movements on a larger scale.

The specificity of production results in the fact that a significant part of this sector employees to work under harsh conditions for little pay (Adamczyk, 2007). "Employees' earnings constitute the key, most difficult and most costly function of human resources management. The key one, as they have a direct impact on obtaining, motivating and keeping the best workers. The most difficult one, as the applied solutions transfer directly into the employees' behaviours and attitudes. Moreover, all input on earnings constitutes a significant component of each employer's costs which is unavoidable" (Beck-Krala, 2012, p. 23). At the same time, low remuneration is one of the reasons for social exclusion (Golinowska et al., 2008). When it affects a large group of people in a local community it constitutes a problem which poses a challenge to public policy. The pork value chain usually has a local dimension. All emerging problems which affect employees translate into public policy, first on a local scale when they affect workers of a particular enterprise or enterprises. When the problem becomes typical for the entire sector it concerns the state public policy (Hausner, 2007). 


\section{Conclusion}

The industry is characterised by a high degree of diversification. On the one hand, there are large companies that integrate several stages of the value chain, and on the other hand, there are many small companies that operate on the verge of profitability. Each part of the pork value chain has its own specific characteristics. Market pressure forces breeders and producers to take action to maintain efficiency. They increase the scale of production and invest in work automation. They look for cost savings, among which labour costs are an important item. Moreover, the pork industry is characterised by high labour intensity. Smaller companies benefit from the work of their families and neighbours, which they compensate for by exchanging services between themselves. They make a limited use of contractual work. Large organisations employ foreigners for unskilled jobs. In periods requiring more intensive work, they benefit from overtime - if the labour market allows it, it is without appropriate remuneration.

These tensions call for more efforts focused on building frameworks and practices of social dialogue within the pork value chain in Poland. Effective social dialogue requires the involvement of all stakeholders, leading to mutual understanding, respect and dialogue, resulting in solutions that meet the needs of the parties. In the case of the pork industry in Poland, the situation is complex. Employees of larger companies look for support in trade unions and associations. They fight for fair labour relations and equal opportunities in the market, e.g. appropriate labelling of the origin of meat. On the basis of the research carried out, it can be concluded that strengthening social dialogue would help to reduce the impact of negative developments in the pork value chain.

The qualitative research carried out was exploratory in nature. Despite the great caution of the interviewees, areas of potential irregularities in industrial relations resulting from imbalances between the parties were identified. A full diagnosis would require additional research, in particular quantitative research. This would make it possible to determine the scale of the phenomena identified. Regulations supporting entities with less negotiating power in industrial relations seem to be the right way to look for solutions. 


\section{References}

Adamczyk, P. (2007). Wydajność pracy a poziom wynagrodzeń osób zatrudnionych w przemyśle mięsnym. Zeszyty Naukowe SGGW - Ekonomika i Organizacja Gospodarki Żywnościowej, 62, 55-65.

Beck-Krala, E. (2012). Ocena efektywności systemów wynagrodzeń. Zarządzanie Zasobami Ludzkimi, 5(88), 23-35.

Bernaciak, M. (2015). Market Expansion and Social Dumping in Europe. Routledge: Taylor and Francis LTD.

Borkowska, S. (1995). Rokowania zbiorowe. In: H. Moerel (Ed.), Zbiorowe stosunki pracy $w$ procesie przemian, Warszawa: IFiS PAN.

Bureau of Analysis and Strategy of the National Agricultural Support Centre (2018). Monthly report on the situation on the agri-food market with elements of development trends, 2/2018.

Eurofound (2016). Social dumping. Retrieved from: https://www.eurofound.europa.eu/ $\mathrm{it} /$ node/86806 (29.09.2019).

Golinowska, S., Morecka, Z., Styrc, M., Cukrowska, E., \& Cukrowski, J. (2008). Od ubóstwa do wykluczenia społecznego. Badania. Koncepcja. Wyniki. Propozycje Polska, Europa i Świat. Warszawa: Opracowania PBZ.

GUS (2017). Agricultural Statistical Yearbook. GUS: Warszawa.

Hausner, J. (2007). Polityka a polityka publiczna, Uniwersytet Ekonomiczny w Krakowie, Małopolska Szkoła Administracji Publicznej. Zarzq̨dzanie Publiczne, 2007/1(1), 43-60.

ILO International Labour Organization (2019). Social dialogue. Retrieved from: https:// www.ilo.org/ifpdial/areas-of-work/social-dialogue/lang--en/index.htm) \%20\%20a (18.11.2019).

Juchnowicz, M. (2011). Dylematy oceny efektywności wynagrodzeń w organizacji gospodarczej. In: P. Bohdziewicz (Ed.), Efektywność gospodarowania kapitałem ludzkim, Łódź: Wydawnictwo Uniwersytetu Łódzkiego.

PKO BP Bank's Report (2018). Meat Industry in Poland.

Swaniewicz, P. (2008). Partnerska Polityka Publiczna na poziomie lokalnym. Pismo Dialogu Społecznego DIALOG.

Szarfenberg, R. (2008). Pojęcie wykluczenia społecznego. Retrieved from: http://rszarf. ips.uw.edu.pl/pdf/pojecie_ws.pdf (19.09.2019).

Szymańska, E.J. (Ed.) (2017). Wyzwania na rynku żywca wieprzowego w Polsce. Warszawa: Wydawnictwo SGGW.

Towalski, R. (2017). Zaufanie jako kluczowy zasób w prowadzeniu dialogu społecznego. Studia z Polityki Publicznej, 15, 47-63.

Weissel, E. (1995). Pakt społeczny w Austrii. In: Negocjacje - droga do paktu społecznego. Doświadczenia, treści, partnerzy i formy, Warszawa: IPiSS. 


\section{Izabela Buchowicz}

Holds a PhD in economics, Assistant Professor of Economics and the Head of the Department of Education and Science Policy at SGH Warsaw School of Economics. She has many years of experience in research and teaching. Her research interests are in the field of education policy, public policy education, children and the youth from disadvantaged backgrounds and students with disabilities. She participates in studies and research regarding the theory and practice of public policy. e-mail address: ibucho@sgh.waw.pl

\section{Hanna Kinowska}

Holds a PhD in economics, Assistant Professor at the Institute of Human Capital at SGH Warsaw School of Economics, lecturer, author of many publications on human capital management. Associated with practice, she has carried out numerous projects improving human capital management, especially in the areas of remuneration systems and employee engagement.

e-mail address: hkinows@sgh.waw.pl

\section{Łukasz Sienkiewicz}

Habilitated $\mathrm{PhD}$ in the field of social sciences in the discipline of management and quality science, Associate Professor at the Institute of Human Capital at SGH Warsaw School of Economics. He specialises in human capital management and labour market issues. In the years 2012-2015, the leader of the Human Capital as an element of the enterprise value project under which an innovative and unique in the country tool for measuring human capital was created. Author and co-author of over 80 peer-reviewed scientific publications (in the field of human capital measurement, competence management, job evaluation and assessment, career and talent management, strategic HRM and labour market) and over 80 expert opinions for the European Commission and economic practice.

e-mail address: 1sienk@sgh.waw.pl 